\title{
ANALYSIS OF CHINA'S FOREIGN POLICY OF BUILDING OF HARMONIOUS WORLD; RELEVANCE FOR PAKISTAN
}

\author{
Waseem Ishaque ${ }^{*}$ \\ Saima Sheikh $^{* *}$
}

\begin{abstract}
China, a lofty nation of 5000 years of uninterrupted civilization, world's second largest economy, a nation of huge land mass and vibrant 1.3 billion populations with permanent seat in United Nation's Security Council is steadfast on the road of peaceful development. Despite foreign aggressions, humiliations and occupations, Chinese nation never demonstrated revengeful attitude and instead adopted a submissive and nonconfrontational approach to buy time for national cohesion, economic and infrastructure development and making the country stronger. The consistent and rapid industrialization has enabled China to maintain over 9\% growth rate which brought rich dividends for China and is now termed as economic super power and world's manufacturing industry. This all can be attributed to consistent pragmatic foreign policy and unique blend of relevant to all and friend of all with mutual accommodation and peaceful coexistence. Pakistan and China are termed as Iron Brothers, therefore, Pakistan can accrue many dividends from rising status of China. This research article critically examines evolution of China's foreign policy and draws relevance for Pakistan with suggested course of actions to make more dynamic and pragmatic foreign policy. The views and analysis expressed in this article are author's own.
\end{abstract}

Keywords: Peaceful co-existence, mutual accommodation, common development, building harmonious world

\section{Introduction}

The grand strategy of China is imaginably most profoundly inclined by its need for steady and reasonably high levels of economic development. The principal purpose for Deng Xiaoping's 24 character strategy "observe calmly, secure our position, cope with affairs calmly, hide our capacities, bide our time, be good at maintaining a low profile, and never claim leadership" " was to buy time for consistent focus and build solid foundations for economic. Over the last three decades since its reform and opening up, China has made a remarkable progress. It has maintained an average close to 8 percent annual growth rate beside substantially improving its military capabilities on land, sea, air and venturing into the space with remarkable degree of success. I as the author of this paper am aware of limitations of not an expert on the subject. My research is based on empirical review of the available literature and background studies on China.

\footnotetext{
${ }^{*}$ WaseemIshaque, Ph.D. Student, Department of Sociology, University of Sindh, Jamshoro

** Saima Sheikh, Ph.D. Chairperson Department of Sociology, University of Sindh, Jamshoro

${ }^{1}$ Deng Xiaoping's 24-Character Strategy emerged in 1990.
} 
Therefore, sincere effort has been made to reflect my understanding of Foreign Policy of China.

\section{Significance of Article}

Pakistan and China friendship dates back to the establishment of People's Republic of China (PRC) in 1949, which has evolved over a period of time from "all weather friends" to now "Iron Brothers". This relationship is unique and role modal in the contemporary history of interstate relations. China is now economic giant with significant influence in international scene. China's successes can be attributed largely to pragmatic foreign policy based on the fundamental principles of "Punchashel". Peaceful coexistence and common development through a win-win cooperation is at the heart of China's foreign policy. Being close friend and next door neighbour, Pakistan has a modal to follow in the form of success story of China's foreign policy. This research article critically examines the evolution of China's foreign policy, draws relevance for Pakistan and proffers recommendations for making significant changes to Pakistan's foreign policy.

\section{Research Methodology}

This article contains rich descriptive data, therefore, qualitative research method has been used to collect and analyze the data. Primary and secondary sources in the form of transcripts, press statements, and books / articles have been used in building, analyzing and proving the validity of arguments.

\section{Qualitative Research Questions}

In pursuance with qualitative research methodology in constructing, analyzing and logically proving the arguments, qualitative research questions have been formulated in format of positivist method of research questions;

Q 1: How China's foreign policy has evolved over different time periods where consistency in strategic outlook has been maintained?

Q 2: What are the contemporary trends in China's foreign policy which make it unique in contemporary international order?

Q 3: What are the fundamental principles of China's foreign policy emphasizing building of harmonious world?

Q 4: What is the relevance of China's foreign policy modal for Pakistan, and how Pakistan can make policy adjustments?

\section{Analytical Debate on Evolution of Chinese Foreign Policy}

\section{First Phase 1949-1959}

Soon after the formation of PRC, the China heavily depended on Soviet political and economic support for at-least initial one decade. Gigantic work on reconstruction, infrastructure development and rehabilitation commenced with Soviet support after 
decades of internal disorder and as national policy the Soviet economic and political model was adopted. Due to obvious cold war rivalry, the West headed by the USA, perceived China as a potential threat to international security due to her alignment with Moscow. The Chinese discernment led her to believe that the newly liberated countries of Asia will ultimately stand up to challenge the existing order of imperialism. The China commenced to develop ties and distinctiveness of interests with the governments of newly independent Afro-Asian countries, while pragmatically relying on its alliance with the Soviet Union for security and international support. One of the landmark achievements of China's foreign policy during initial days was historic agreement on rules of business which have generally been referred as Five Principles of Peaceful Coexistence or "Panchsheel" on $29^{\text {th }}$ April 1954. These principles eventually became the foundation of China's foreign policy and are recurrently raised by the Chinese leaders both at home and abroad, which are; "Mutual respect for each other's territorial integrity and Sovereignty, Mutual non-aggression, Mutual non-interference in each other's internal affairs, Equality and mutual benefit and Peaceful coexistence."2

\section{Second Phase 1959-1978}

The second phase in the development of China's foreign policy commenced during 1960. This phase was most critical as Sino-Soviet rift of 1959 encouraged India for adopting more aggressive policy against China. At this stage, China was faced with foreign policy dilemma of hostile India on one hand and hostile Soviet Union on the other, apart from virtual state of international isolation. China passed through many crises during this period. It is important to note that the friendship with Pakistan developed and assumed great significance for both countries during this era. Regionally, in 1962, China imposed a military defeat on India in retaliation to Indian aggression; while internationally, it was confronting the hostility of two super powers. Apart from political and security challenges, China was also confronting serious economic hardships following the failure of Great Leap Forward policies initiated in 1958. China pursued to cultivate countervailing relationships focusing on African, Asian and Latin American countries. The years 1964 and 1965 witnessed critical gains in China-Pakistan friendship. In 1971 the Sino-US rapprochement occurred, which paved the way for President Nixon's historical visit to China in 1972. In this period, China was also restored to its welldeserved place in the UN. With the sad demise of Chairman Mao in 1976, Deng Xiaoping was enabled to follow pragmatic approach of opening up which ultimately propelled China on the track of development and modernization commencing in 1978.

\section{Third Phase 1978 Onwards}

The third and the ongoing phase of Chinese foreign policy, "accorded the highest priority to economic development with modernization as the key object." 3 Deng Xiaoping emphasized on "economic development at centre, advocated hiding capabilities and biding for time." "Whereas holding the basic principles of its foreign policy, China has made significant and profound accomplishments. The most noteworthy change was to

\footnotetext{
${ }^{2}$ Maqbool Ahmed Bhatty, China's Peaceful rise \& South Asia, Islamabad Policy Research Institute, 2008,p.3

${ }^{3}$ Ibid.,p 8

${ }^{4}$ PJS Sandhu, Rising China, Opportunity or Strategic Challenge, Vij Books New Delhi India,2010,p.46
} 
transform the economy along entrepreneurial lines while retaining the overall political control of Communist Party of China (CPC). China unequivocally announced to open up to the outside world, predominantly to encourage international community and their advanced technology which were appreciated to be vital for achieving the economic prosperity goals set forth. To achieve the objective of economic development and modernization, China does not want itself to be engaged in any regional or global disputes. Deng Xiaoping's oft repeated dictum in this regard as "Keep a low profile and never take the lead"s. This concept calls for focusing on economic objectives, engaging all countries for smooth flow of investments and technology and even postponing conflicts for a long time, except on core sovereignty issues. China also dedicated itself to enhancing its role in the multi-lateral domain, "stressing regional cooperation and making the UN system a more effective instrument of peace and development". ${ }^{6}$

\section{Contemporary Trends in China's Foreign Policy and Future Projections}

\section{New Security Concept}

At the meeting of ASEAN Regional Forum (ARF) in march1997, the China announced her vision about new security concept and advocated "to rise above one-sided security and seek common security through mutually beneficial cooperation". ${ }^{7}$ China reiterated that territorial disputes are no longer an obstacle for China and surrounding neighbours to advance collaboration to establish good-neighbourly relations and cooperatively build regional security. Through this concept, China has pursued to advance its relationship with ASEAN countries and persuade countries in the region that the perception of "China threat is illusory". ${ }^{\circ}$

\section{The Good and Friendly Neighbourhood Policy}

China considers it in her national interest to safeguard durable peace and stability in Asia. Stating China's Asia Policy, President Hu Jintao (Boao Forum 15 ${ }^{\text {th }}$ April 2011) said, "China cannot achieve development without Asia and Asia cannot realize prosperity without China. It is the consistent policy of the Chinese government to strengthen the good neighbourly and friendly relations with its surrounding countries". ${ }^{9}$ It is based on the conception of "befriending and maintaining good relationships with neighbours" (yilinwei ban, yilinweishan). And directed by the model of "be harmonious, pacify and enrich thy neighbors" ( $m$ u lin, an lin, fulin). This new approach is intended towards the quest of regional collaboration.

\section{The Peaceful Development and Harmonious World Policy}

In 2003, China suggested the Peaceful Development policy. Despite the proclamation of peaceful intent in this vision, it generated mixed response from the world community as well as neighboring states. China's development was being viewed with suspicion due to

\footnotetext{
${ }_{6}^{5}$ Ibid., p.49

${ }^{6}$ Maqbool Ahmed Bhatty, Op.cit., p.11

${ }^{7}$ Ministry of Foreign Affairs of the Peoples Republic of China, Paper on the New Security Concept.

${ }^{8} \mathrm{Ibid}$.

${ }^{9}$ President Hu Jintao's key note address at Boao Forum on 15 April 2011
} 
Realist notion of Power Politics in anarchic international order. Chinese Vice Foreign Minister Wang Yi on 10 March 2004 stated that "While safeguarding national interests, China will also keep up with international trends". ${ }^{10}$ At the $60^{\text {th }}$ anniversary summit of the UN on 15 September 2005, President Hu Jintao announced a vision for building a Harmonious World through his four point suggestions. These were; "Multilateralism should be upheld to realize common security, mutually beneficial cooperation should be upheld to realize common prosperity, upholding the spirit of inclusiveness to build a world where all civilizations co-exist harmoniously and accommodate each other, rational and necessary reform of the UN to maintain its authority and efficacy". ${ }^{11}$ China's practical steps in line with these objectives make it abundantly clear that the good neighbourly line to diplomacy embraced in its harmonious world conception has developed the basic design for its global scheme. In his report to the $17^{\text {th }}$ Party Congress on 15 October 2007, President Hu Jintao stated that China will continue to carry forward the good neighbour diplomatic policy of "befriending and maintaining good relationship with neighbours and actively expanding regional cooperation". ${ }^{12}$

\section{Fundamental Principles of China's Foreign Policy}

\section{Principles of Foreign Policy}

"China's foreign policy has evolved on the basis of its historical legacy, its experience of foreign domination during the period of Western colonialism, and its national goals of modernization and development." ${ }^{13}$ From its inception, the People's Republic of China adopted certain principles, which have been retained as the foundation of its foreign policy, despite changes of leadership and pragmatic adjustments to the evolving global scene.

Maintaining Independent Foreign Policy. China follow sin dependent foreign policy where-by it seeks no expansión or hege mony and would never allow inter ferance in her affairs.

Oppositionto Hegemonic Tendencies. China is opposed to all sorts of hegemonic trends and tendencies, whether they are international or regional. China believes that all countries irrespective of their power and status are equal and respectable members of the international community.

Five Principles of Peaceful Coexistance. China strives to grow mutually valuable collaboration with all the countries of the world, notwithstanding their social associations on the foundations of the five principles of mutual respect for sovereignty and territorial integrity, peaceful coexistence, mutual non-aggression, non-interference in each other's internal affairs, mutual benefit and equality, and peaceful coexistence.

Rectification of Historical Wrongs. China is dedicated to the modification of historical wrongs for which it grieved most on the aspects of territorial integrity and in the

\footnotetext{
${ }^{10}$ Chinese Vice Foreign Minister Wang Yi, 10 March 2004

${ }^{11}$ President Hu Jintao's speech at UN New York on 15 September 2005

${ }^{12}$ Full text of Hu Jinato's report at the $17^{\text {th }}$ Party Congress on 15 October 2007

${ }^{13}$ Bhatty, M.A.Op.cit., p. 29
} 
reaffirmation of its reunification of Taiwan and several islands off its coast. However, it pursues to resolve these concerns through peaceful means.

Self-Image as Developing Country. "China regards itself as being the largest developing country and therefore tries to stand up with and support the developing countries in their quest for a fair and rational international economic order."14

\section{Contemporary Foreign Policy Philosophy of China}

On 1 March 2007, MrQin Gang, the Foreign Ministry spokesperson outlined "eight-point diplomatic philosophy of China.,"15

China will not Seek Hegemony. Even when China becomes a developed country in long term, it will never seek hegemony. China will not impose its ideology on others, will never play power politics and will not interfere in internal affairs of any country.

Equal Treatment with Respect. China upholds that all countries should be treated with respect and equality. All affairs should be consulted and resolved on the basis of equal participation and no country should be able to intimidate others on the basis of strength.

No Double Standards. China will make judgment on each case / matter in international affairs based on the merit and will not have double standards in her conduct. Upheld UN Charter. China promotes that all countries handle interstate relations on the foundations of the United Nations Charter and advocates international cooperation.

Peaceful Settlement of Disputes. China supports peaceful conciliation and discussions to resolve disputes. China does not recourse to force, or threat of force in determining disputes. China preserves a reasonable national military strength to defend its sovereignty with no intention to expand or aggression.

No to Terrorism and Weapons Proliferation. China is resolutely opposed to terrorism and the proliferation of weapons of mass destruction. China is a responsible member of the international community, and as for international treaties, China accepts by all them in a sincere manner.

Respect for Civilizations. China respects the assortment of civilizations and the entire world. China promotes cultural exchanges, learn from each other and supplement one another with their respective strengths. China is strongly opposed to clatters between civilizations and China does not link any particular ethnic group or religion with terrorism.

\section{President Xi Jinping's Foreign Policy Vision}

On taking over the office of President of PRC, Mr Xi Jinping elaborated fundamental foreign policy principles to be adopted by his government for realizing the China's dream.

${ }^{14}$ PJS Sandhu, Op.cit., p.43

${ }^{15}$ Transcript of, Mr Qin Gang, the Foreign Ministry spokespersonof 1 March 2007 
The main strands of his vision are; striving for a peaceful international environment to develop itself and promoting world peace through its own development, to strive to promote coordinated development among major powers, to consistently enhance the good neighbourhood and friendly relationship with neighboring countries; to maintain peace and stability in peripheral area, to deepen the cooperation and unity with developing countries, China adheres to an autonomous foreign policy of peace and on the foundation of five principles of peaceful co-existence, China will develop cooperative and friendly relations with all the countries of the world.

\section{Analysison Contemporary Trends in China's Foreign Policy}

\section{Prime Aims of China's Foreign Policy}

China seeks to achieve rejuvenation, create peaceful external environment, and through rapid transformation develop its economy. Therefore, Chinese foreign policy pursues peaceful relations with other states and conforming to the principles of justice and fair play.

\section{Independent Foreign Policy}

China is pursuing independent foreign policy for peace. The basic purposes of the policy focus on safeguarding sovereignty and independence and creating peaceful and harmonious international environment. China does not seek expansion or hegemony and will not side by any power seeking hegemony.

\section{Unveiling of Current Foreign Policy}

Since Mr Xi Jinping assumed office, China is pursuing state-of-the-art initiatives with the purpose of building harmonious world. Three distinct features can be seen in Mr Xi's foreign policy outlook; first examining issues pragmatically from a more global perspective instead of China centric outlook, second China is willing to assume greater responsibility on the matters of global importance and third greater emphasis on innovation and awareness.

\section{Responsible Great Power Status}

In Beijing on 27June 2013 T World Peace Forum, the Foreign Minister of China Wang $\mathrm{Yi}$ stated that "China had to become a great power and pursue great-power relations but that it should not do so in the mold of previous great powers. This means that China will not tolerate interference from foreign forces in its diplomatic decisions and will not seek alliances or hegemony. Instead, Beijing will pursue a path of peaceful development. "This evidently satisfies international audience that China's development and elevation to great power status will not be a threat to any country.

\section{Emerging International Order}

Today's international system is based on multidimensional and multi-mode networks of information age. Whether it is an enterprise, an individual, a country, it is appreciated that 
no single object can exist without a network. China is pragmatically balancing itself in the networks like BRICS (Brazil, Russia, India, China, and South Africa), the SCO (Shanghai Cooperation Organization) and ASEAN (association of south east Asian Nation). China has also encouraged reforms in the international organizations such as the IMF, the World Bank, and the UN.

\section{Resolution of Disputes}

China seeks resolution of disputes through negotiations and peaceful means. As a permanent Security Council member, China has conducted its foreign relations and principle stand on issues of global importance in a very balanced and graceful manner, which has raised her stature in the comity of nations.

\section{Relevance and Recommendations for Pakistan}

Pakistan and China are all weather friends and Iron brothers sharing commonality of views on regional stability and economic development. The rising stature of China is a balancer for South Asia being its near abroad and overall great source of solidity and economic development of the world at large. China's foreign policy and rapid pace of economic development have complemented each other, which in 30 years only has made her economic super power of contemporary times. Pakistan has a lot to learn both on diplomatic and economic front from China. Its dream of building harmonious world through win-win cooperation and creating shared destiny of common interests is indeed exceptional in the antiquity of International Relations. Being the best friend of Pakistan, China is ready to support in all domains. Therefore, Pakistan has to capitalize from the prevailing environment for eventual benefit of Pakistani nation. Following is therefore recommended:-

\section{Skillful Diplomacy}

China's skillful diplomacy in creating harmonious world and non-interference in other's affairs has raised her undisputed stature in the comity of nations. The same policy is recommended to be adopted by Pakistan for future to avoid diplomatic isolation.

\section{Balance of Power}

China's independent foreign policy has created space for more active participation in the international affairs. China as a permanent member of UNSC is will continue its rightful voice for bringing enduring world peace and harmony. Pakistan must capitalize on Chinese stature and conduct her independent foreign policy by the space provided by China through rising multi polarity.

\section{Proactive Foreign Policy}

China's peaceful development and comprehensive national power potential has enabled her to be an active global player. Despite turbulent international landscape, China has successfully kept her near abroad in peace. It is appreciated that China will not involve in power politics of any great power and cannot be subdued despite provocations. China is 
proud of her achievements as these milestones have been covered not at the cost of any other country or bloc, but own hard work and sincere dedication, therefore, China will not be apologetic on west's negative propaganda on human rights issues etc. Pakistan has to energize foreign office and her diplomatic missions abroad and conduct proactive and result oriented foreign policy aimed at avoiding diplomatic isolation and positively projecting Pakistan's sacrifices especially during ongoing efforts of eliminating menace of terrorism and extremism. The enhanced international engagements should attract foreign investments and revive tourism as these are vital for Pakistan's economic revival.

\section{Dispute Resolution}

China has demonstrated highest degree of statecraft and pragmatism in dealing with conflicting issues and resolving those amicably with mutual accommodation. Her policy of economy first and enhancing economic interdependence for raising stakes and creating favourable environment of dispute resolution not bound by strict timelines can be very helpful for Pakistan. Similar mechanism is worth trying for Pakistan as another alternate without compromising core national interests.

\section{Creating Community of Common Interests and Shared Destiny}

China has taken every nation on board and wants to benefit from her economic development to all relevant countries and the regions. Pakistan enjoys special place in foreign policy calculus of China, therefore, can benefit enormously from this policy. Chinese promised investment of around US\$ 46 billion for CPEC under overall vision of One Belt One Road is testimony of this fact, which is perceived to be a game changer not only for Pakistan but also the entire region. The economic and infrastructure connectivity will be helpful in make Pakistan a Centre of Gravity and Regional Economic Hub, if Pakistan remains relevant in execution of her foreign and domestic policies.

\section{Concluding Results of Research Article}

As per the research methodology, results portion contain the main crux of findings research article. As per author's analyses, the China is following the foreign policy of friendly relations with all the countries, peaceful resolution of disputes, building community of common interests and shared destiny, seeking common development through a win-win cooperation. China does not want to alter the existing international order, instead wants to transform it for betterment of all states, regions and world at large without challenging the statuesque power. China also does not seek hegemony, nor allows hegemonic tendencies to flourish as these are against the norms of $21^{\text {st }}$ century outside cold war mentality of containment. With regards to relevance to Pakistan, it must be appreciated that China is time tested friend of Pakistan and through self reliance and pragmatic foreign policy, China has raised her international stature and become most influential member of international community on all the major forums. Pakistan can replicate some of measures and modify her foreign policy orientation to make to pragmatic and forward looking for enhancing international relevance and stature. China's good offices can be used as leverage in capitalizing on regional peace initiatives as a reliable partner and responsible member of international community. 


\section{Conclusion}

Ever since her inception in 1949, China has adopted balanced, pragmatic and independent foreign policy which undoubtedly has made China as one of the greatest nation in the world. China in her foreign policy conduct will endorse the banner of development, peace, cooperation and unswervingly adhere to peaceful progress, follow a win-win strategy and developing friendly cooperation with all countries in the world and promote the lofty cause of peace and progress of manhood with other nations. President Xi Jin Ping quote is worth mentioning here, "Peace is like air and sunshine. It is unconscious when we are benefiting from it. But none of us can live without it." The demonstrated policy of peaceful coexistence, shelving disputes, principal stand on core national interests and economic development through win - win cooperation avoiding zero sum gains in the conduct of International Relations are the visible success stories from which Pakistan can replicate.

\section{Bibliography}

C Fred Bergsten, China's Foreign Policy, www.chinabalancesheet.org (10 February 2017)

Chinese Vice Foreign Minister Wang Yi, 10 March 2004

Deng Xiaoping's 24-Character Strategy emerged in

1990, http://www.globalsecurity.org/military/world/china/24-character.htm (10 February 2017)

Foreign Policy Actor, Asia Programme Paper ASP 2011/05, www.chatamhouse.org (10 February 2017)

Maqbool Ahmed Bhatty, China's Peaceful rise and South Asia, Islamabad Policy

Research Institute Pakistan, 2008

Ministry of Foreign Affairs of the Peoples Republic of China, Paper on the New Security Concept, http://www.fmprc.gov.cn/eng/ (10 February 2017)

PJS Sandhu, Rising China, Opportunity or Strategic Challenge, Vij Books New Delhi India, 2010

President Hu Jintao's key note address at Boao Forum on 15 April 2011, http://news.xinhuanet.com/english2010/china/2011-04/15/c_13830786.htm (10 February 2017)

President Hu Jintao's speech at UN New York on 15 September 2005, http://www.un.org/webcast/summit2005/statements15/china050915eng.pdf (10 February 2017)

Zhu Liqun, China's Foreign Policy Debates, Chaillot Papers, ISS Paris France, 2010 